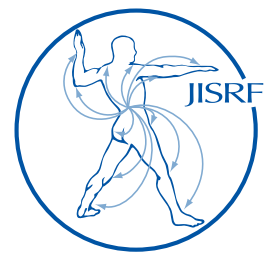

\title{
The Performance of Mixed Manufacturer Metal On Metal Total Hip Replacements
}

Cook $R^{1}$, Latham $J^{1}$, Wood $R^{1}$

\section{Abstract}

Using a femoral head from one manufacturer on the stem of another manufacturer poses the risk that the taper interface between the components may not contact correctly and the performance of the joint will be impaired. The cohorts in this study are a combination of modular Birmingham Hip Resurfacing (BHR) and Adept femoral heads on CPT stems. The study reviews the geometry of the taper interfaces to establish if the taper clearance angles was outside of the normal range for other taper interfaces. In addition the rates of material loss from the bearings and taper and a ranking of the stem damage were reviewed to determine if the levels of loss were above that seen for other similar joints.

The material loss analysis demonstrated that the rates or levels of loss from the bearings, taper and stem were no different to levels published for manufacturer matched joints and in many cases were lower. The results demonstrate that the taper clearance angles for the mixed manufacturer joints (BHR-CPT: 0.067 to -0.116 , Adept-CPT: 0.101 to -0.056 ) were within the range of other studies and manufacturer matched clearances $(0.134$ to -0.149$)$.

Using components from different manufacturers has not in this instance increased the level of material loss from the joints, when compared to other similar manufacturer matched joints.

Keywords: total hip; mix and match; metal on metal

Level of Evidence: AAOS Therapeutic Level III

\section{Introduction}

The use of large diameter Cobalt Chromium femoral head components in total hip replacements has come under scrutiny due to the poor performance of these joints in-vivo. In particular the performance of the taper junction between the head and femoral components. The use of mixed manufacturer components has been a particular area of focus, where the manufacturers' variation in angle of their 12/14 tapers can result in different taper clearance angles and contact lengths 1 from those specified by the manufacturers.
1 Dr Richard Barker Cook, PhD; Professor Robert J K Wood, FREng, CEng, FIMechE, MICorr, FIMMM, FHEA, MInstPhys University of Southampton, University Road, Southampton, SO17 1BJ, UK (Direct reprint requests to Richard Cook)

2 Jeremy M Latham, MA, MCh, FRCS(Orth)

Southampton University Hospitals NHS Trust, remona Rd, Southampton SO16 6YD, UK

(c) 2017 Cook, Wood. All rights reserved.

Authors retain copyright and grant the journal right of first publication with the work. Reconstructive Review is an open access publication and follows the Creative Commons Attribution-Non-

Commercial CC BY-NC. This license allows anyone to download works, build upon the material, and share them with others for non-commercial purposes as long as they credit the senior author, Reconstructive Review, and the Joint Implant Surgery \& Research Foundation (JISRF). An example credit would be: "Courtesy of (senior author's name), Reconstructive Review, JISRF, Chagrin Falls, Ohio". 


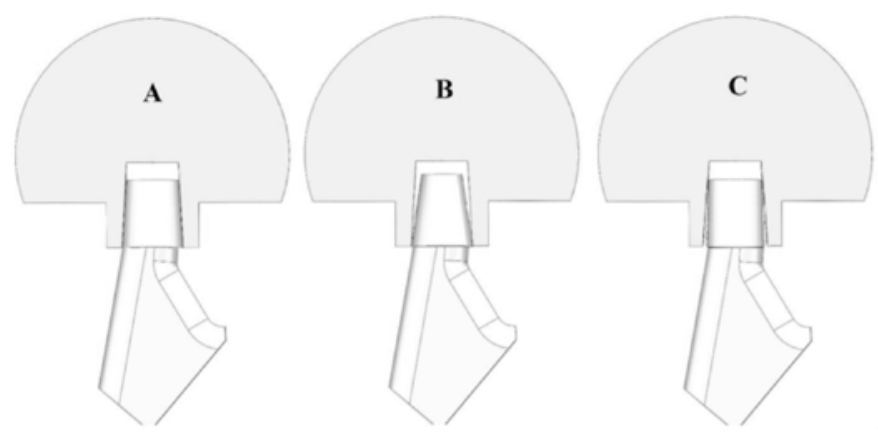

Figure 1. Taper Clearance Angle definition. A. Full length contact, taper angle $=$ trunnion angle, clearance $=0 . B$. Distal contact, taper angle $<$ trunnion angle, Clearance $<0$. C. Proximal Contact, taper angle $>$ trunnion angle, Clearance $>0$

The taper clearance angle provides a means of assessing how the male and female components of a taper will contact (Figure 1). A positive clearance indicates that the taper would have contacted at the proximal / narrow diameter end of the taper, while a negative clearance is the opposite, with a distal contact at the larger diameter end of the interface. The angles for the ASR and Articuleze joints presented by Langton et al [르 were $5.670^{\circ}\left(5.568^{\circ}\right.$ to $\left.5.798^{\circ}\right)$ and $5.639^{\circ}\left(5.584^{\circ}\right.$ to $\left.5.685^{\circ}\right)$ (taper engagement level identified data) which, when paired with the $5^{\circ} 43^{\prime}$ Corail trunnion [ $\underline{3}$ ], provide clearances of $-0.047^{\circ}\left(-0.149^{\circ}\right.$ to $\left.0.081^{\circ}\right)$ and $-0.078^{\circ}\left(-0.133^{\circ}\right.$ to $\left.-0.032^{\circ}\right)$ degrees. This range of clearance angles and differences in design specification is further reflected in the study of Kocagöz et al. [1] whose cohort of 50 metal femoral head had a 35:15 split between positive and negative clearance angles. The range of taper clearances within the study [1] was 7.5 to -8 arcminutes $\left(0.125^{\circ}\right.$ to $\left.-0.133^{\circ}\right)$, with $50 \%$ of the values between 5 and -2 arcminutes $\left(0.083^{\circ}\right.$ to $\left.-0.033^{\circ}\right)$.

This analysis demonstrates that there is no consistent or single design philosophy for taper contacts between manufacturers, with some opting for proximal contacts and positive clearances and others for distal contacts and negative clearances. In the case of the ASR - Corail pairings the variation in the measured angle of the tapers provide both positive and negative clearances on the same trunnion.

The analysis of retrieved joints has highlighted three sources of material loss; the bearing surfaces [늠], the taper interface [ $[-11]$ and the cement-stem interface $[\underline{12}, \underline{13}]$ each capable of triggering a reaction significant enough to require revision surgery. The ability of bearing surface wear to cause adverse reactions is clear from the retrieval studies [느므 focused on resurfacing joints. The ability of the material loss from the taper interface to initiate adverse reactions can be demonstrated by the increasing numbers of failures in metal on polymer bearings [7-11]. The issue of debris from the cement stem interface was demonstrated by the work of Donnell et al. and Bryant et al. on the Ultima hip replacement system $[\underline{12}, \underline{13}]$, with Hothi et al. [14] showing that damage was present on seven different designs of cemented stem.

The literature contains a number of retrieval studies where the values of linear $[\underline{6}, \underline{15}-\underline{19}]$ and volumetric loss $[\underline{15}, \underline{19}-24]$ from the bearing surfaces of metal on metal joints have been presented (Table 1). However, in most studies, the values for edge-wearing components have not been differentiated from those without edge wear, meaning the values provided are not reflective of the true wear rates for these joints. Only two studies [ $[\underline{6}, 17]$ provided linear wear rates and only one provides volumetric rates [22] which are representative of the bearing performance of well aligned components in-vivo (mean bearings combined: $1.10 \mathrm{~mm} 3 / \mathrm{yr}$ ).

There are eight studies $[\underline{2}, \underline{19}, \underline{21}, \underline{23}-\underline{27}]$ in the literature which have quantified the material loss from the surfaces of female tapers of both manufacturer matched and mixed manufacturer metal on metal joints (Table 2). The published mean volumetric wear rates from these studies range from 0.85 to $0.127 \mathrm{~mm} 3 /$ year, with median values ranging from 0.132 and $0.238 \mathrm{~mm} 3 /$ year (Table 2).

Cook et al. [28] assessed the volume of material lost from the surfaces of cemented stems, showing mean rates of loss between $(0.003$ and $1.9 \mathrm{~mm} 3 / \mathrm{yr})$, however these measures has a $+/-16 \%$ error due to the both the complexity and variability in the geometry of different components. The accepted method for the characterization of the level of damage to cemented stems is the 5 level ranking developed by Bryant et al. [12]. Two studies have utilized this score, Bryant et al. [12] who provided a mean score of 2.9 for 105 manufacturer matched cemented components, and Hothi et al. [14] who, while not providing an average value, reported 27 of the 36 stems reviewed as having a score of 3 or over.

These previously published values of material loss and ranking obtained from retrieved metal on metal joints, provide the baseline against which the performance of other joints can be compared. The objective of this study is to determine how the levels of material loss from three sites on a group of mixed manufacturer joints relates to other previously reported levels of material loss from manufacturer matched joints. We hypothesize that the level of material loss from the bearings, taper and cement stem interfaces will not exceed that of other joint designs. 
Table 1: Linear and Volumetric Wear Rates of the bearings surfaces of metal on metal joints

\begin{tabular}{|c|c|c|c|c|c|c|c|c|c|c|c|}
\hline \multirow[b]{2}{*}{ Study } & \multirow[b]{2}{*}{$\begin{array}{l}\text { Number of } \\
\text { Hips }\end{array}$} & \multirow[b]{2}{*}{ Joint Deign } & & \multirow[b]{2}{*}{$\begin{array}{c}\text { Edge worn : non-edge } \\
\text { worn }\end{array}$} & \multirow[b]{2}{*}{$\begin{array}{l}\text { Time In-Vivo } \\
\text { (Years) }\end{array}$} & \multicolumn{2}{|c|}{ Femoral Head } & \multicolumn{2}{|c|}{ Acetabular Cup } & \multicolumn{2}{|c|}{ Bearings Combined } \\
\hline & & & & & & $\begin{array}{l}\text { Linear Rate } \\
\left(\mu \mathrm{m}^{3} / \text { year }\right)\end{array}$ & $\begin{array}{l}\text { Volumetric } \\
\text { Rate } \\
\text { (mm } \mathrm{mm}^{3} / \text { year) }\end{array}$ & $\begin{array}{l}\text { Linear Rate } \\
\left(\mu \mathrm{m}^{3} / \text { year }\right)\end{array}$ & $\begin{array}{l}\text { Volumetric } \\
\text { Rate } \\
\text { ( } \mathrm{mm}^{3} / \text { year) } \\
\end{array}$ & $\begin{array}{l}\text { Linear Rate } \\
\left(\mu \mathrm{m}^{3} / \text { year }\right)\end{array}$ & $\begin{array}{l}\text { Volumetric Rate } \\
\left(\mathrm{mm}^{3} / \text { year }\right)\end{array}$ \\
\hline \multirow{4}{*}{ Matthies et al. ${ }^{6}$} & \multirow[t]{2}{*}{60} & \multirow[t]{2}{*}{$\begin{array}{l}\text { Modular } \\
\text { THR }\end{array}$} & & Edge Worn: 34 & \multirow[t]{2}{*}{$\begin{array}{l}\text { Mean: } 2.6 \\
(1-6.1)\end{array}$} & & & $\begin{array}{c}\text { Median: } \\
16.87 \\
(0.82- \\
119.15) \\
\end{array}$ & & & \\
\hline & & & & Non-edge worn: 26 & & & & \begin{tabular}{|l|} 
Median: 0.00 \\
$(0.00-4.77)$ \\
\end{tabular} & & & \\
\hline & \multirow[t]{2}{*}{60} & \multirow[t]{2}{*}{ Resurfacing } & & Edge Worn: 40 & \multirow[t]{2}{*}{$\begin{array}{l}\text { Mean: } 3.8 \\
(1-10.1)\end{array}$} & & & $\begin{array}{c}\text { Median: } \\
11.00 \\
(0.77- \\
173.81)\end{array}$ & & & \\
\hline & & & & Non-edge worn: 20 & & & & \begin{tabular}{|c|} 
Median: 0.00 \\
$(0.00-6.18)$ \\
\end{tabular} & & & \\
\hline \multirow[b]{2}{*}{ Kwon et al. ${ }^{16}$} & 9 & \multirow[b]{2}{*}{ Resurfacing } & Pseudotumour & 9:0 & $\begin{array}{l}\text { Mean: } 3.6 \\
(1.1-6.6)\end{array}$ & $\begin{array}{l}\text { Median: } 8.1 \\
(2.75-25.4)\end{array}$ & & \begin{tabular}{|l|} 
Median: 7.36 \\
$(1.61-24.9)$ \\
\end{tabular} & & & \\
\hline & 22 & & $\begin{array}{c}\text { No } \\
\text { Pseudotumour }\end{array}$ & 1:21 & $\begin{array}{l}\text { Mean: } 2.3 \\
(1.0-5.8)\end{array}$ & $\begin{array}{c}\text { Median: } \\
1.79 \\
(0.82-4.15)\end{array}$ & & $\begin{array}{c}\text { Median: } 1.28 \\
(0.18-3.33)\end{array}$ & & & \\
\hline \multirow{2}{*}{ Underwood et al. ${ }^{17}$} & \multirow{2}{*}{122} & \multirow{2}{*}{ Combined } & Edge worn & 78 & & & & \begin{tabular}{|c|} 
Mean: 31.90 \\
$(0.77-245.55)$ \\
\end{tabular} & & & \\
\hline & & & Non-edge worn & 44 & & & & $\begin{array}{c}\text { Mean: } 0.85 \\
(0-6.18)\end{array}$ & & & \\
\hline \multirow{2}{*}{ Matthies et al. ${ }^{18}$} & 72 & \multirow{2}{*}{ Combined } & Pseudotumour & & $\begin{array}{l}\text { Mean: } 3.1 \\
(1-5.75)\end{array}$ & $\begin{array}{c}\text { Median: } 5.3 \\
(0-84.1) \\
\end{array}$ & & $\begin{array}{c}\text { Median: } 6.8 \\
(0-180) \\
\end{array}$ & & & \\
\hline & 33 & & Control & & $\begin{array}{l}\text { Mean: } 3.3 \\
(1.1-7.9)\end{array}$ & $\begin{array}{l}\text { Median: } 2 \\
(0-62.1)\end{array}$ & & $\begin{array}{c}\text { Median: } 2.2 \\
(0-64.3)\end{array}$ & & & \\
\hline Hart et al. ${ }^{29}$ & 45 & Resurfacing & & & Mean: 2.7 & Median: 8.7 & & Median: 5.6 & & & \\
\hline \multirow{2}{*}{ Glyn-Jones et al. ${ }^{15}$} & 18 & \multirow{2}{*}{ Resurfacing } & Pseudotumour & $7: 11$ & $\begin{array}{l}\text { Mean: } 3.9 \\
\text { SD: } 2.1\end{array}$ & $\begin{array}{l}\text { Mean: } 8.4 \\
\text { SD: } 8.7\end{array}$ & $\begin{array}{l}\text { Mean: } 3.3 \\
\text { SD: } 5.7\end{array}$ & $\begin{array}{l}\text { Mean: } 16.1 \\
\text { SD: } 21.4\end{array}$ & $\begin{array}{l}\text { Mean: } 2.5 \\
\text { SD: } 6.3\end{array}$ & & \\
\hline & 18 & & Control & $6: 12$ & $\begin{array}{l}\text { Mean: } 2.5 \\
\text { SD: } 1.9\end{array}$ & $\begin{array}{l}\text { Mean: } 2.9 \\
\text { SD: } 3.9\end{array}$ & $\begin{array}{l}\text { Mean: } 0.8 \\
\text { SD: } 1.2\end{array}$ & $\begin{array}{l}\text { Mean: } 1.0 \\
\text { SD: } 1.5\end{array}$ & $\begin{array}{l}\text { Mean: } 0.4 \\
\text { SD: } 0.8\end{array}$ & & \\
\hline \multirow{5}{*}{ Nawabi et al. ${ }^{19}$} & \multirow[b]{2}{*}{94} & \multirow[b]{2}{*}{ Combined } & Unexplained Pain & $8: 27$ & $\begin{array}{l}\text { Mean: } 3.25 \\
(1.5-8.6)\end{array}$ & & & & & $\begin{array}{l}\text { Median: } 2.6 \\
(0-128.2)\end{array}$ & $\begin{array}{l}\text { Median:0.3 } \\
(0-29.3)\end{array}$ \\
\hline & & & Control & $37: 22$ & $\begin{array}{l}\text { Mean: } 2.5 \\
(1-6.5)\end{array}$ & & & & & $\begin{array}{c}\text { Median: } \\
12.8 \\
(0-232.1)\end{array}$ & $\begin{array}{l}\text { Median:1.5 } \\
(0-94.3)\end{array}$ \\
\hline & 10 & Resurfacing & Combined & & $\begin{array}{l}\text { Mean: } 1.9 \\
(1.5-4.2)\end{array}$ & & & & & $\begin{array}{l}\text { Median: } 3.3 \\
(0-128.2)\end{array}$ & $\begin{array}{l}\text { Median:0.3 } \\
(0-26.2)\end{array}$ \\
\hline & 24 & THR & Combined & & Mean: 3.75 & & & & & Median: 2.2 & Median:0.3 \\
\hline & & & & & $(1.5-8.6)$ & & & & & $(0-85.6)$ & $(0-29.3)$ \\
\hline Morlock et al. ${ }^{22}$ & $\begin{array}{l}12 \text { Heads } \\
17 \text { Cup }\end{array}$ & Resurfacing & Non-edge worn & & & & $\begin{array}{l}\text { Mean: } 0.402 \\
\text { SD: } 0.584\end{array}$ & & $\begin{array}{c}\text { Mean: } 0.584 \\
\text { SD: } 1.39 \\
\end{array}$ & & $\begin{array}{l}\text { Mean: } 1.10 \\
\text { SD: } 1.7\end{array}$ \\
\hline Witt et al. ${ }^{30}$ & $\begin{array}{l}30 \text { Heads } \\
28 \text { Cups }\end{array}$ & $\begin{array}{l}\text { Modular } \\
\text { THR }\end{array}$ & Combined & & $\begin{array}{l}\text { Mean: } 3.5 \\
\text { SD: } 1.6\end{array}$ & & $\begin{array}{l}\text { Mean: } 1.96 \\
\text { SD: } 4.92\end{array}$ & & $\begin{array}{l}\text { Mean: } 1.05 \\
\text { SD: } 2.25\end{array}$ & & \\
\hline Lord et al. ${ }^{20}$ & $\begin{array}{l}32 \text { Heads } \\
22 \text { Cups }\end{array}$ & Resurfacing & Combined & & & & $\begin{array}{c}\text { Mean: } 8.72 \\
(0.21-31.91) \\
\end{array}$ & & $\begin{array}{l}\text { Mean: } 11.02 \\
(0.30-63.59) \\
\end{array}$ & & $\begin{array}{l}\text { Mean: } 22.66 \\
(0.51-95.50( \\
\end{array}$ \\
\hline & $\begin{array}{c}10 \\
\text { S-ROM stem }\end{array}$ & $\begin{array}{l}\text { Modular } \\
\text { THR }\end{array}$ & Combined & & $\begin{array}{l}\text { Mean: } 5.3 \\
(3.3-7)\end{array}$ & & & & & & $\begin{array}{l}\text { Median: } 3.92 \\
(1.20-7.81) \\
\end{array}$ \\
\hline Hothi et al. ${ }^{23}$ & $\begin{array}{c}10 \\
\text { Corail stem }\end{array}$ & $\begin{array}{l}\text { Modular } \\
\text { THR }\end{array}$ & Combined & & $\begin{array}{l}\text { Mean: } 4.7 \\
(4.2-6.4)\end{array}$ & & & & & & $\begin{array}{l}\text { Median: } 3.21 \\
\text { Range: } 0.87- \\
62.12\end{array}$ \\
\hline Matthies et al. ${ }^{21}$ & 110 & $\begin{array}{l}\text { Modular } \\
\text { THR }\end{array}$ & Combined & & $\begin{array}{l}\text { Mean: } 3.7 \\
(1-7.1)\end{array}$ & & $\begin{array}{c}\text { Mean: } 3.10 \\
\text { Median:1.31 } \\
(0.06-45.66) \\
\end{array}$ & & $\begin{array}{c}\text { Mean: } 2.56 \\
\text { Median:0.62 } \\
(0.04-39.62) \\
\end{array}$ & & \\
\hline Sidaginamale et al. & 116 & $\begin{array}{c}\text { Modular } \\
\text { THR }\end{array}$ & Combined & & $\begin{array}{l}\text { Mean: } 4.8 \\
(0.6-9.1)\end{array}$ & & & & & & $\begin{array}{c}\text { Median: } 2.02 \\
0.27-68.9 \\
\end{array}$ \\
\hline & 83 & Resurfacing & Combined & & & & & & & & $\begin{array}{c}\text { Median: } 7.35 \\
\text { Range: } 0.62-95.5 \\
\end{array}$ \\
\hline & $22 \mathrm{BHR}$ & $\begin{array}{l}\text { Modular } \\
\text { THR }\end{array}$ & Combined & $16: 8$ & $\begin{array}{l}\text { Mean: } 7.5 \\
(4.7-9.6)\end{array}$ & $\begin{array}{c}\text { Mean: } 4.5 \\
\text { Median: } 2.5 \\
(0.9-39)\end{array}$ & $\begin{array}{l}\text { Mean: } 1.99 \\
\text { Median: } 0.7 \\
(0.17-21.1) \\
\end{array}$ & $\begin{array}{c}\text { Mean: } 7.3 \\
\text { Median: } 1 \\
(0.4-105.2) \\
\end{array}$ & $\begin{array}{c}\text { Mean: } 2.94 \\
\text { Median: } 0.43 \\
(0.11-45.2) \\
\end{array}$ & & $\begin{array}{c}\text { Mean: } 4.94 \\
\text { Median: } 1.15 \\
(0.36-66.4) \\
\end{array}$ \\
\hline This Study & 22 Adept & $\begin{array}{l}\text { Modular } \\
\text { THR }\end{array}$ & Combined & $10: 12$ & $\begin{array}{l}\text { Mean: } 6.8 \\
(3.3-10.3)\end{array}$ & $\begin{array}{c}\text { Mean:1.9 } \\
\text { Median: } \\
1.4 \\
(0.3-9)\end{array}$ & $\begin{array}{c}\text { Mean: } 0.57 \\
\text { Median: } 0.28 \\
(0.08-4.7)\end{array}$ & $\begin{array}{l}\text { Mean: } 3.9 \\
\text { Median: } 1.8 \\
(0-29.6)\end{array}$ & $\begin{array}{c}\text { Mean: } 1.41 \\
\text { Median: } 0.38 \\
(0-16.7)\end{array}$ & & $\begin{array}{c}\text { Mean: } 2.07 \\
\text { Median: } 0.74 \\
(0.19-21.4)\end{array}$ \\
\hline & $16 \mathrm{BHR}$ & $\begin{array}{l}\text { Modular } \\
\text { THR }\end{array}$ & Non-edge worn & & $\begin{array}{l}\text { Mean: } 7.3 \\
(4.7-9.6)\end{array}$ & $\begin{array}{c}\text { Mean: } 1.9 \\
\text { Median: } 1.5 \\
(0.9-3.6)\end{array}$ & $\begin{array}{l}\text { Mean: } 0.55 \\
\text { Median: } 0.4 \\
(0.17-1.46) \\
\end{array}$ & $\begin{array}{c}\text { Mean: } 0.9 \\
\text { Median: } 0.8 \\
(0.4-1.5)\end{array}$ & $\begin{array}{c}\text { Mean: } 0.40 \\
\text { Median: } 0.33 \\
(0.1-1)\end{array}$ & & $\begin{array}{l}\text { Mean: } 0.96 \\
\text { Median: } 0.74 \\
(0.36-2.28)\end{array}$ \\
\hline & 10 Adept & $\begin{array}{l}\text { Modular } \\
\text { THR }\end{array}$ & Non-edge worn & & $\begin{array}{l}\text { Mean: } 6.2 \\
(3.3-10.3)\end{array}$ & $\begin{array}{c}\text { Mean: } 1 \\
\text { Median: } 0.8 \\
(0.3-2.1)\end{array}$ & $\begin{array}{c}\text { Mean: } 0.24 \\
\text { Median: } 0.21 \\
(0.08-0.5)\end{array}$ & $\begin{array}{c}\text { Mean: } 0.9 \\
\text { Median: } 0.6 \\
(0-2.8)\end{array}$ & $\begin{array}{c}\text { Mean: } 0.37 \\
\text { Median: } 0.22 \\
(0-1.6)\end{array}$ & & $\begin{array}{c}\text { Mean: } 0.41 \\
\text { Median: } 0.32 \\
(0.12-0.94)\end{array}$ \\
\hline
\end{tabular}

\section{Materials and Methods}

\section{Study demographics}

The implants reviewed within this study are shown in Table 3. They are mixed manufacturer head and stem combinations formed of cemented collarless tapered cobaltchrome Zimmer CPT stems paired with either an Adept
LDMH (Finsbury Orthopaedics) $(\mathrm{n}=22)$ or a BHR large diameter modular head (LDMH) (Midland Medical technologies; Smith and Nephew) ( $\mathrm{n}=22)$.

Ethical approval was granted by the National Research Ethics Service Committee South Central = Southampton A. 


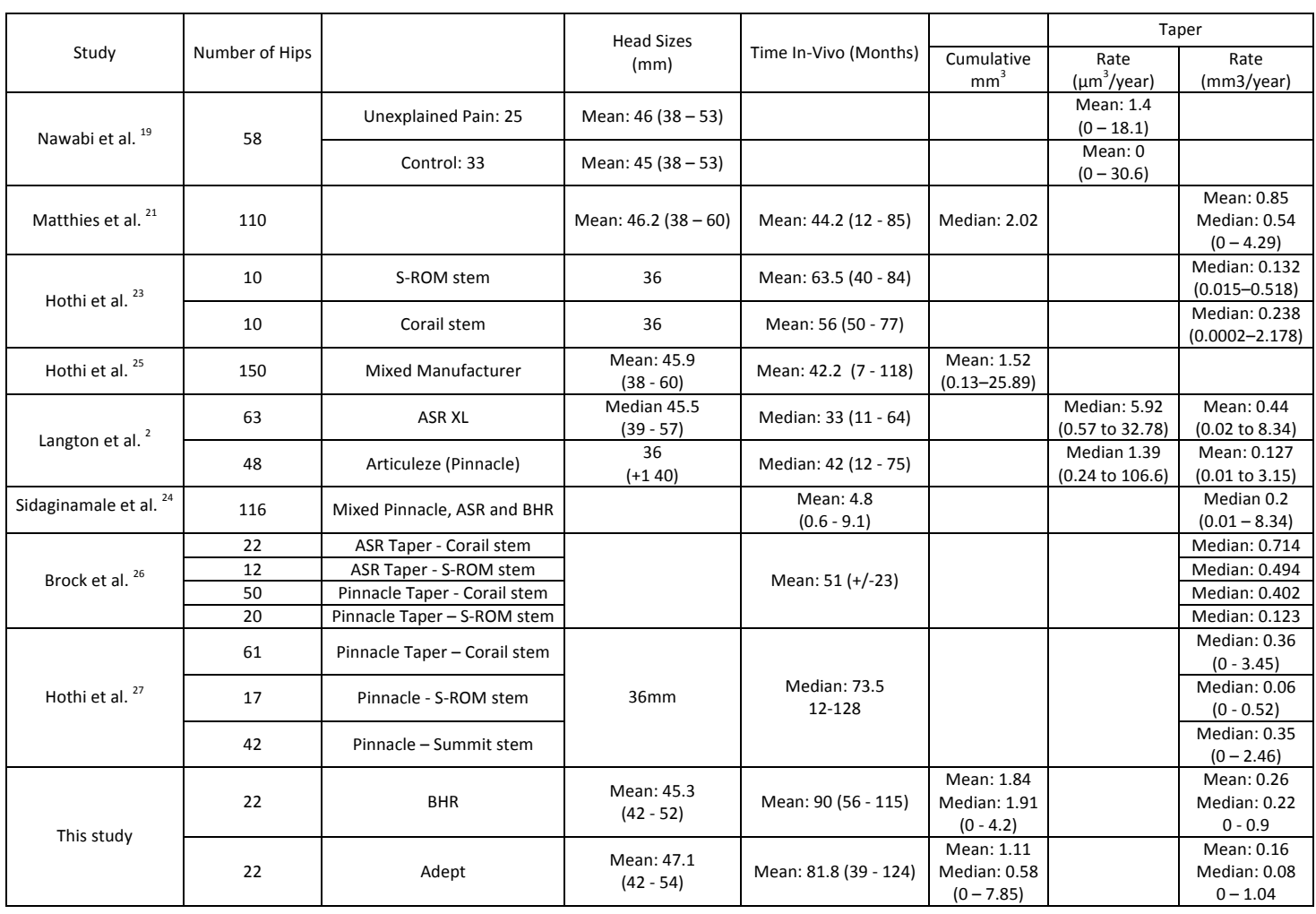

Table 2. Linear and Volumetric Wear Rates from tapers of metal on metal joints

\begin{tabular}{|l|l|l|}
\hline & BHR & Adept \\
\hline Number of joints & 22 & 22 \\
\hline Time In-Situ & 90 & 82 \\
(months) & $(56-115)$ & $(39-124)$ \\
\hline Head Size & $42 \mathrm{~mm} \mathrm{n}=8$ & $42 \mathrm{~mm} \mathrm{n}=3$ \\
& $46 \mathrm{~mm}, \mathrm{n}=10$ & $44 \mathrm{~mm} \mathrm{n}=1$ \\
& $50 \mathrm{~mm}, \mathrm{n}=4$ & $46 \mathrm{~mm} \mathrm{n}=7$ \\
& & $48 \mathrm{~mm} \mathrm{n}=5$ \\
& & $50 \mathrm{~mm} \mathrm{n}=5$ \\
& & $54 \mathrm{~mm} \mathrm{n}=1$ \\
\hline
\end{tabular}

\section{Table 3 Joint}

Demographics.

Table 4 Mean, Median and range of values of material loss from the implant surfaces

\begin{tabular}{|c|c|c|c|c|c|c|c|c|c|c|c|c|}
\hline & & BHR-CPT & Adept-CPT & & BHR-CPT & Adept-CPT & & BHR-CPT & Adept-CPT & & BHR-CPT & Adept-CPT \\
\hline Normal Wear: Edge Wear & & $16: 6$ & 10:12 & & & & & & & & & \\
\hline $\begin{array}{l}\text { Clearance } \\
(\mathrm{mm})\end{array}$ & & $\begin{array}{c}0.220 \\
0.211 \\
0.16-0.33\end{array}$ & $\begin{array}{c}0.181 \\
0.180 \\
0.13-0.23\end{array}$ & & & & & & & \multirow{9}{*}{ 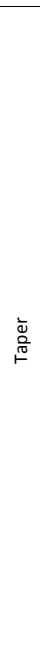 } & & \\
\hline $\begin{array}{l}\text { All Samples Cumulative } \\
\text { Linear Loss } \\
(\mu \mathrm{m})\end{array}$ & \multirow{8}{*}{ 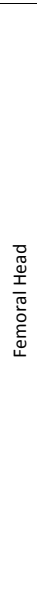 } & $\begin{array}{c}35 \\
18.5 \\
5-318\end{array}$ & $\begin{array}{c}12.6 \\
7.7 \\
2-56.5\end{array}$ & \multirow{8}{*}{ 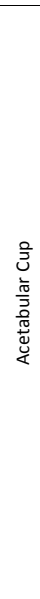 } & $\begin{array}{c}58 \\
7.3 \\
2.7-859\end{array}$ & $\begin{array}{c}27 \\
11 \\
0-190\end{array}$ & \multirow{8}{*}{ 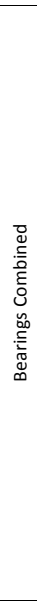 } & & & & & \\
\hline $\begin{array}{l}\text { All Samples Linear Loss rate } \\
\qquad(\mu \mathrm{m} / \mathrm{yr})\end{array}$ & & $\begin{array}{c}4.5 \\
2.5 \\
0.9-39\end{array}$ & $\begin{array}{c}1.9 \\
1.4 \\
0.3-9\end{array}$ & & $\begin{array}{c}7.3 \\
1 \\
0.4-105.2\end{array}$ & $\begin{array}{c}3.9 \\
1.8 \\
0-29.6\end{array}$ & & & & & & \\
\hline $\begin{array}{c}\text { Non-edge Wearing Cumulative } \\
\text { Linear Loss } \\
(\mu \mathrm{m})\end{array}$ & & $\begin{array}{c}14 \\
11 \\
5.2-24 \\
\end{array}$ & $\begin{array}{c}5.3 \\
5.9 \\
2.3-8.6 \\
\end{array}$ & & $\begin{array}{c}6 \\
6 \\
3-12.8 \\
\end{array}$ & $\begin{array}{c}5.3 \\
4.7 \\
0-19.5 \\
\end{array}$ & & & & & & \\
\hline $\begin{array}{l}\text { Non-edge Wearing Linear Loss rate } \\
\qquad(\mu \mathrm{m} / \mathrm{yr})\end{array}$ & & $\begin{array}{c}1.9 \\
1.5 \\
0.9-3.6\end{array}$ & $\begin{array}{c}1 \\
0.8 \\
0.3-2.1\end{array}$ & & $\begin{array}{c}0.9 \\
0.8 \\
0.4-1.5\end{array}$ & $\begin{array}{c}0.9 \\
0.6 \\
0-2.8\end{array}$ & & & & & & \\
\hline $\begin{array}{l}\text { All Samples Cumulative Volume Loss } \\
\qquad\left(\mathrm{mm}^{3}\right)\end{array}$ & & $\begin{array}{c}15.64 \\
5 \\
1.13-172.6\end{array}$ & $\begin{array}{c}4.62 \\
2.1 \\
0.6-30.4 \\
\end{array}$ & & $\begin{array}{c}23.38 \\
3.49 \\
0.5-369.3\end{array}$ & $\begin{array}{c}9.18 \\
3.09 \\
0-107.1\end{array}$ & & $\begin{array}{c}39.02 \\
9 \\
1.73-541.9 \\
\end{array}$ & \begin{tabular}{|c|}
13.80 \\
4.97 \\
$0.6-137.5$ \\
\end{tabular} & & $\begin{array}{c}1.84 \\
1.91 \\
0-4.2\end{array}$ & $\begin{array}{c}1.11 \\
0.58 \\
0-7.85\end{array}$ \\
\hline $\begin{array}{l}\text { All Samples Volume Loss rate } \\
\qquad\left(\mathrm{mm}^{3} / \mathrm{yr}\right)\end{array}$ & & $\begin{array}{c}1.99 \\
0.7 \\
0.17-21.1\end{array}$ & $\begin{array}{c}0.57 \\
0.28 \\
0.08-4.7\end{array}$ & & $\begin{array}{c}2.94 \\
0.43 \\
0.11-45.2\end{array}$ & $\begin{array}{l}1.41 \\
0.38 \\
0-16.7\end{array}$ & & \begin{tabular}{|c|}
4.94 \\
1.15 \\
$0.36-66.4$
\end{tabular} & \begin{tabular}{|c|}
2.07 \\
0.74 \\
$0.19-21.4$
\end{tabular} & & $\begin{array}{c}0.26 \\
0.22 \\
0-0.9\end{array}$ & $\begin{array}{c}0.16 \\
0.08 \\
0-1.04\end{array}$ \\
\hline $\begin{array}{c}\text { Non-edge Wearing Cumulative } \\
\text { Volume Loss } \\
\left(\mathrm{mm}^{3}\right)\end{array}$ & & $\begin{array}{c}3.98 \\
2.8 \\
1.13-8.6 \\
\end{array}$ & $\begin{array}{c}1.36 \\
1.45 \\
0.6-2.1 \\
\end{array}$ & & \begin{tabular}{c|}
2.94 \\
2.20 \\
$0.5-7.6$ \\
\end{tabular} & $\begin{array}{l}1.88 \\
1.57 \\
0-6.3 \\
\end{array}$ & & \begin{tabular}{|c|}
6.92 \\
5.87 \\
$1.73-13.62$ \\
\end{tabular} & \begin{tabular}{|c|}
2.26 \\
2 \\
$0.6-3.92$ \\
\end{tabular} & & \begin{tabular}{c|}
1.97 \\
2.34 \\
$0-4.2$ \\
\end{tabular} & $\begin{array}{c}0.76 \\
0.47 \\
0-1.9 \\
\end{array}$ \\
\hline $\begin{array}{l}\text { Non-edge Wearing Volume } \\
\text { Loss rate } \\
\left(\mathrm{mm}^{3} / \mathrm{yr}\right)\end{array}$ & & $\begin{array}{c}0.55 \\
0.4 \\
0.17-1.46\end{array}$ & $\begin{array}{c}0.24 \\
0.21 \\
0.08-0.5\end{array}$ & & $\begin{array}{c}0.40 \\
0.33 \\
0.1-1\end{array}$ & $\begin{array}{c}0.37 \\
0.22 \\
0-1.6 \\
\end{array}$ & & \begin{tabular}{c|}
0.96 \\
0.74 \\
$0.36-2.28$
\end{tabular} & \begin{tabular}{|c|}
0.61 \\
0.32 \\
$0.12-0.94$ \\
\end{tabular} & & $\begin{array}{c}0.28 \\
0.30 \\
0-0.9\end{array}$ & $\begin{array}{c}0.14 \\
0.08 \\
0-0.4\end{array}$ \\
\hline
\end{tabular}

\section{Material loss assessment}

The volumetric material loss measurements for the bearing and taper surfaces of each joint in the study were obtained using a non-contact optical coordinate measuring machine (OrthoLux, RedLux, Southampton UK). The measurement procedure and validation for spherical components can be found in Tuke et al. [31]. Direct assessment of the bearing surfaces was performed with a point cloud density of 1 point per degree circumferentially and 1 point per degree from the pole to the edge. The regions of damage on the bearing surfaces were identified and removed and a sphere fitted to the remaining points. The linear wear was assessed as the maximum linear deviation from the fitted sphere in the center of the wear scar and the volumetric loss measured as the volume beneath the fitted sphere and the assessed surface within the wear scar region.

The taper assessments were performed on a casting of the taper surface. The casting was made using Microset 202 (Microset Products Ltd, 


\begin{tabular}{|c|c|c|c|c|c|c|c|}
\hline \multirow[b]{2}{*}{$\begin{array}{c}\text { Bearing } \\
\text { Manufacturer }\end{array}$} & \multirow[b]{2}{*}{$\begin{array}{c}\text { Retrieved head Taper } \\
\text { Angle } \\
\text { (Degrees) }\end{array}$} & \multicolumn{2}{|c|}{ Vs. CPT Trunnion angle of $5^{\circ} 40^{\prime}$ or $5.667^{\circ}$} & \multicolumn{2}{|c|}{$\begin{array}{l}\text { Vs. Zweymuller Trunnion angle of } 5^{\circ} 38^{\prime} \text { or } \\
5.633^{\circ}\end{array}$} & \multicolumn{2}{|c|}{$\begin{array}{l}\text { Vs. Synergy Trunnion angle of } 5^{\circ} 40^{\prime} \text { secs or } \\
5.667^{\circ}\end{array}$} \\
\hline & & $\begin{array}{l}\text { Taper Angle } \\
\text { Clearance } \\
\text { (Degrees) }\end{array}$ & $\begin{array}{l}\text { Taper Angle } \\
\text { Clearance } \\
\text { (Minutes) }\end{array}$ & $\begin{array}{c}\text { Taper Angle } \\
\text { Clearance } \\
\text { (Degrees) }\end{array}$ & $\begin{array}{l}\text { Taper Angle } \\
\text { Clearance } \\
\text { (Minutes) }\end{array}$ & $\begin{array}{c}\text { Taper Angle } \\
\text { Clearance } \\
\text { (Degrees) }\end{array}$ & $\begin{array}{l}\text { Taper Angle } \\
\text { Clearance } \\
\text { (Minutes) }\end{array}$ \\
\hline $\begin{array}{l}\text { Adept } \\
n=22\end{array}$ & $\begin{array}{c}5.690^{\circ} \\
5.696^{\circ} \\
\left(5.610^{\circ}-5.767^{\circ}\right)\end{array}$ & $\begin{array}{c}0.024^{\circ} \\
0.030^{\circ} \\
\left(0.101^{\circ} \text { to }-0.056^{\circ}\right)\end{array}$ & $\begin{array}{c}1.463 \\
1.799 \\
(1.799 \text { to }-3.333)\end{array}$ & $\begin{array}{c}0.057^{\circ} \\
0.063^{\circ} \\
\left(0.134^{\circ} \text { to }-0.023^{\circ}\right)\end{array}$ & $\begin{array}{c}3.443 \\
3.779 \\
(3.779 \text { to }-1.353)\end{array}$ & - & - \\
\hline $\begin{array}{l}\text { BHR } \\
n=22\end{array}$ & $\begin{array}{c}5.662^{\circ} \\
5.663^{\circ} \\
\left(5.551^{\circ}-5.734^{\circ}\right)\end{array}$ & $\begin{array}{c}-0.005^{\circ} \\
-0.005^{\circ} \\
\left(0.067^{\circ} \text { to }-0.116^{\circ}\right)\end{array}$ & $\begin{array}{c}-0.314 \\
-0.272 \\
(4.030 \text { to }-6.961)\end{array}$ & - & - & $\begin{array}{c}-0.005^{\circ} \\
-0.005^{\circ} \\
\left(0.067^{\circ} \text { to }-0.116^{\circ}\right)\end{array}$ & $\begin{array}{c}-0.314 \\
-0.272 \\
(4.030 \text { to }-6.961)\end{array}$ \\
\hline Metasul & - & $-0.034^{\circ}$ & $\begin{array}{l}-2.04 \\
\end{array}$ & - & - & - & - \\
\hline
\end{tabular}

Table 5: Table 3 Mean, median and range of the Taper Angles and Clearance angles.

Nuneaton, UK) replication material which has the ability to reproduce the surface with a resolution of $0.05 \mu \mathrm{m}$. The measurements of the taper surface were collected with a point density of 2 points per degree circumferentially and 70 points per $\mathrm{mm}$ along the length. The damaged regions of the taper surface and any regions with material deposits were excluded and a cone fitted to the remaining original surface. The volumetric loss was assessed as the volume beneath the fitted cone within the wear scar region. Validation of this method has been published [32] and the limits of agreement $(95 \%)$ of the material loss were -0.0416 to $0.173 \mathrm{~mm} 3$ with a taper angle shown to be within $0.0024^{\circ}$.

Volumetric loss and the angles of the retrieved trunnions was not assessed. The surfaces of the trunnions were perceived to have some level of deformation or damage along their full lengths. This provided no original surface to which to apply a cone fit, meaning any volumetric value or angle assessment would have had unquantifiable and inconsistent levels of error, with the magnitude of the error varying with the level of damage to the trunnion. In order to assess the taper clearance angles, the manufacturers stated trunnion angle for the CPT ( $5^{\circ} 40$ minutes), as well as the Finsbury orthopedics Zweymuller Alloclassic ( $5^{\circ} 38$ minutes) [33] and the Synergy stem ( $5^{\circ} 40$ minutes) were gathered. The Alloclassic stem and the synergy stem represent the manufacturer matched stem parings for the Adept and BHR heads. It is of note that both the BHR and Adept heads were marketed initially without a specified stem pairing and these were subsequently identified as appropriate. In addition the Metasul and Durom female taper ( $5^{\circ} 38$ minutes) [34] was reviewed in relation to the CPT trunnion to define manufacturers specified taper clearance for this pairing.

\section{Stem grading}

The stems were graded using the criteria described by Bryant et al. 2013 [4]. The scale classifies stems into one of five categories based on the area of damage to the stem surface from within the cemented region. The categories are 1: $<10 \%, 2: 10-25 \%, 3: 25-50 \%$ 4: $50-75 \%$ and $5:>75 \%$ of the surface.

\section{Results}

The bearing surface analysis identified 18 out of the 44 joints $(\mathrm{BHR}=6$, Adept $=12)$ as being edge worn. The exclusion of the edge wearing joints from the data sets, provided a mean wear rate for the joints in-vivo of 0.24 and $0.55 \mathrm{~mm}^{3} /$ year for the femoral heads and 0.37 and 0.4 $\mathrm{mm}^{3} /$ year for the acetabular cups of the Adept and BHR joints respectively (Table 4). The wear rate of the non-edge worn femoral heads was significantly higher for the BHR joints $(p=0.006)$, but there was no significant difference between the levels from the acetabular cups ( $p=0.865)$.

Analysis of the tapers demonstrated a range of levels of material loss. The mean rate of volumetric loss from the Adept and BHR female taper surfaces respectively was 0.16 and $0.26 \mathrm{~mm}^{3} /$ year (Table 4). Comparison of the means of the two rate of loss using a 2 sample t-test showed there was no statistically significant difference $(\mathrm{p}=0.179)$. There was also no significant difference between the rates of volume loss from the tapers of the joints with edge worn bearings and those without for either the BHR ( $p=0.113)$, the Adept pairings $(\mathrm{p}=0.639)$ or the two groups combined $(\mathrm{p}=0.444)$.

All of the stems examined displayed evidence of damage to their surfaces which would have been within the cement mantle. The mean Bryant score for the BHR and Adept coupled stems was 2.4 and 2.9 respectively. There was no statistically significant difference in the level of stem damage between the BHR and Adept groups ( $p=0.498)$, nor was there a significant difference in the stem score for the edge worn and non-edge worn bearings (BHR: $\mathrm{p}=$ 0.481, Adept: $\mathrm{p}=0.899$, combined: $\mathrm{p}=0.763$ ).

The assessment of the BHR and Adept female taper surfaces showed a difference in the mean taper angle $\left(5.690^{\circ}\right.$ vs. $5.662^{\circ}$ respectively). This difference in the taper angle of the two joints was approaching significance $(\mathrm{p}=$ 0.054). The taper angles of the joints resulted in different taper clearance angles when compared to the manufacturer specified trunnion angle for the CPT (Table 5). The BHR taper angle was similar to that of the CPT trunnion, but provided a negative clearance of -0.005 degrees. In con- 
trast the Adept taper provided a positive clearance angle of $0.024^{\circ}$. Based on the taper angles assessed in this study, the manufacturer matched pairings would have provided mean clearances of $0.057^{\circ}$ and $-0.005^{\circ}$ for the Adept-Alloclassic and the BHR-Synergy respectively and $-0.034^{\circ}$ for the Metasul-CPT, Table 5.

The correlation between the head size, bearing clearance, time in-situ, offset, taper angle and taper clearance vs. ideal CPT (tapers only) on the volume of loss from the bearing surfaces and the taper and the stem grading was investigated. The only significant correlations were found between the BHR taper loss and the head size $(r=0.438, \mathrm{p}$ $=0.042$ ) and the CPT derived offset with the stem grading of the Adept group $(\mathrm{r}=-0.577, \mathrm{p}=0.019)$.

\section{Inter site}

When the volume of material loss from the bearings was compared to that of the taper and the stem grading from the whole data set $(n=44)$, only one significant correlation was found between the bearing surface wear and the stem grading $($ Head $r=-0.435, p=0.007$, Cup $r=-0.333, p=$ 0.044). However, removal of an edge worn BHR sample which had lost $172.6 \mathrm{~mm}^{3}$ and $369.3 \mathrm{~mm}^{3}$ from the femoral head and acetabular cup respectively rendered this relationship non-significant.

Separate analysis considering the different joint designs and the edge worn and non-edge worn joints separately failed to provide any significant correlations between the material lost from the different sites.

\section{Discussion}

In order to determine if the bearing surfaces were performing as would be expected, the results from the wear analysis in this study need to be compared to those of previous studies on similar joints. Table 1 contains linear $[\underline{6}, \underline{15}-\underline{19}]$ and volumetric loss $[\underline{15}, \underline{19}-\underline{24}]$ measures from the bearing surfaces of retrieved metal on metal joints. However, in most studies, the values for edge-wearing components have not been differentiated from those without edge wear, meaning the values provided by most studies are not reflective of the true wear rate for these joints. Only three $[\underline{6}, \underline{16}, \underline{17}]$ out of the six studies provided linear wear rate values which are representative of a well aligned components in-vivo and two of those only presented values for the acetabular cups.

The mean linear wear rates of reported by Underwood et al. [17] were higher than those reported in this study. However, Matthies et al. [] provided median wear rates for $0 \mu \mathrm{m} /$ year $(0-4.77)$ and $0 \mu \mathrm{m} /$ year $(0-6.18)$. The inference of this is that 37 or more of these 74 retrieved joints had no measureable wear. This may be a reflection of the shorter time in-situ of these joints compared to the current study, or a difference in the ability of the roundness machine measurement technique to pick up low levels of wear compared to the RedLux technique. However the maximum linear wear rates presented for these joints are higher than this study.

The mean volume loss rate of the non-edge wearing femoral head components published by Morlock et al. [22] was lower than from the BHR femoral components in this study. However, the mean volume loss rates from the Adept femoral heads, the acetabular surfaces and the bearings combined for both designs from this study were below the values presented.

When the rates of the whole data, incorporating the edge worn values are compared to the rates of loss those of the previous studies $[\underline{15}, \underline{19}-\underline{23}, \underline{30}]$, the current values sit within the range presented in Table 1 .

The volumetric wear rate of the non-edge wearing joints demonstrate that the BHR joints had double the rate of volume loss from the femoral heads compared to the Adept. This difference can be explained in part by the lower clearance ( $40 \mu \mathrm{m}$ less) of the Adept joints (Table 4). The Adept clearance is high enough to overcome any fears around deformation during insertion [35] and high friction due to lubricant starvation [36], but low enough to reduce the volume lost as a result of the running in wear associated with higher clearance joints $[\underline{17}, \underline{37}]$.

There are eight studies $[\underline{2}, \underline{19}, \underline{21}, \underline{23}-\underline{27}]$ in the literature which have quantified the material loss from the surfaces of female tapers (Table 2). Matthies et al [21] and Hothi et al [23] provide values for the cumulative loss from the surfaces of $2.02 \mathrm{~mm}^{3}$ (Median) and $1.52 \mathrm{~mm}^{3}$ (Mean), higher than the mean and median values in this study for the Adept tapers, but a higher median and lower mean $(0.22 \mathrm{~mm} 3$ difference) when compared to the BHR joints.

Comparing the material loss values in this study with those of previous studies (Table 2), the loss is beneath that of Matthies et al. [21] obtained from a range of different joint designs, Hothi et al. [23] for Corail - Ultamet head pairings and the ASR XL tapers presented by Langton et al. [2]. Only the mean values for the Articuleze-Pinnacle joints (difference BHR: 0.133, Adept: $0.033 \mathrm{~mm}^{3} /$ year) and the median value for the S-Rom stem - Ultamet head parings were less than those presented here. In both of these studies $[\underline{2}, \underline{23}]$ the head sizes were $36 \mathrm{~mm}$ which is $6 \mathrm{~mm}$ smaller than the smallest head considered in this cohort, a known variable in the performance of tapers and the S-Rom stem also has an 11/13 taper rather than a 12/14 which may have influenced the performance. 
Comparison of the volumes of loss from the bearings to the taper and stem showed no significant correlations, demonstrating that the loss occurring at these individual sites was independent of what was occurring at the other sites. The results also showed no correlation between joint specific variables such as offset, clearance, head size and time in-situ and the levels of material loss.

The clearance angles for the combinations in this study are within the range presented by Kocagöz et al. [1] and the manufacturers, with the average clearance for each group maintaining the positive or negative clearance which would have been specified for that joint design. The clearance angles were not correlated to the volume of loss from the taper, in agreement with the findings of Kocagöz et al. [1] for the visual grading of taper damage vs. taper clearance.

The closer match of angle seen in the current mixed manufacturer taper and trunnions has advantages. The taper engagement length between the two surfaces will be higher than those with a more extreme taper clearance and larger engagement lengths have been shown to reduce the volume loss from the taper [23]. The horizontal lever arm of distally contacting tapers detailed by Langton et al. [2] will be reduced, which has also been linked to heightened volume loss [2] and the gap between the two surfaces at the larger diameter (open) end of the proximally contacting tapers will be reduced, minimizing the access to fluid entering the interface.

It is clear from this study that there is no consensus on what is an appropriate taper clearance angle. The clearance angles for manufacturer matched pairings demonstrate that the Metasul-CPT and BHR Synergy tapers were designed with a negative clearance of $-0.034^{\circ}$ and $-0.005^{\circ}$ respectively, while the Adept-Alloclassic pairing had a positive clearance of $0.057^{\circ}$. Different manufacturers have designed for different clearances and contact locations. The clearances within the study by Langton et al. [2] for the ASR-Corail pairings $\left(-0.149^{\circ}\right.$ to $\left.0.081^{\circ}\right)$, the BHR-synergy parings $\left(-0.116^{\circ}\right.$ to $\left.0.067^{\circ}\right)$ and the Adept-Alloclassic pairings $(-0.023$ to 0.134$)$ in this study, demonstrate that both negative and positive clearance angles are possible within the same joint design on a particular stem due to the tolerances of the taper manufacturing.

A review of cemented stems within the previous studies [12-14, $\underline{38}-\underline{42}]$, demonstrates that damage is identifiable on a range of designs and materials. Using the data available in the Bryant et al. [12] paper, it was possible to demonstrate that there was no significant difference between the mean stem damage rankings in their study and this work $(\mathrm{p}=0.147)$.

It is of note that while the performance of the three interfaces with regards to material loss does not differ and is in many cases better than manufacturer matched options. These joints had the potential to suffer from material loss at all three interfaces, which in combination elevated the overall volume of material released into the patient.

\section{Conclusions}

This study has shown that the material loss from the bearing, taper and cement-stem interface of these mixed manufacturer total hip replacements is equal to and in many cases lower than that published by other centers for manufacturer matched joints. The taper clearance angles of these mixed manufacturer joint pairings are within the normal range for modular taper connections of manufacturer matched joints and has maintained the proximal or distal nature of the taper which the manufacturer matched joints would have produced. The use of mixed manufacturer joints has not in this instance adversely affected the performance of the joints when compared to other similar manufacturer matched joints.

\section{Acknowledgements}

The authors would like to acknowledge the EPSRC for funding through the grant reference EP/F034296/1. All data supporting this study are openly available from the University of Southampton repository at: http://doi. org/10.5258/SOTON/D0127

\section{Disclosure}

The authors declare that there is no conflict of interest regarding the publication of this paper. For full disclosures refer to last page of this journal.

1. Kocagöz SB, Underwood RJ, Sivan S, Gilbert JL, MacDonald DW, Day JS, Kurtz SM. Does taper angle clearance influence fretting and corrosion damage at the head-stem interface? A matched cohort retrieval study. Seminars in arthroplasty. Vol. 24: Elsevier, 2013:246-54.

2. Langton DJ, Sidaginamale R, Lord JK, Nargol AV, Joyce TJ. Taper junction failure in large-diameter metalon-metal bearings. Bone Joint Res 2012:1-4:56-63.

Bone MC, Sidaginamale RP, Lord JK, Scholes SC, Joyce TJ, Nargol AV, Langton DJ. Determining material loss from the femoral stem trunnion in hip arthroplasty using a coordinate measuring machine. Proceedings of the Institution of Mechanical Engineers, Part H: Journal of Engineering in Medicine 2015;229-1:69-76.

4. Glyn-Jones S, Pandit H, Kwon Y-M, Doll H, Gill HS, Murray DW. Risk factors for inflammatory pseudotumour formation following hip resurfacing. Journal of Bone \& Joint Surgery, British Volume 2009;91-B12:1566-74.

5. Langton DJ, Jameson SS, Joyce TJ, Hallab NJ, Natu S, Nargol AVF. Early failure of metal-on-metal bearings in hip resurfacing and large-diameter total hip replacement: A CONSEQUENCE OF EXCESS WEAR. Journal of Bone \& Joint Surgery, British Volume 2010;92-B-1:38-46.

6. Matthies A, Underwood R, Cann P, Ilo K, Nawaz Z, Skinner J, Hart AJ. Retrieval analysis of 240 metal-onmetal hip components, comparing modular total hip replacement with hip resurfacing. Journal of Bone \& Joint Surgery, British Volume 2011;93-B-3:307-14.

7. Cook RB, Bolland BJRF, Wharton JA, Tilley S, Latham JM, Wood RJK. Pseudotumour Formation Due to Tribocorrosion at the Taper Interface of Large Diameter Metal on Polymer Modular Total Hip Replacements. Journal of Arthroplasty 2013;28-8:1430-6.

8. Gill IPS, Webb J, Sloan K, Beaver RJ. Corrosion at the neck-stem junction as a cause of metal ion release and pseudotumour formation. Journal of Bone \& Joint Surgery, British Volume 2012;94-B-7:895-900.

Fricka KB, Ho H, Peace WJ, Engh Jr CA. Metal-on-Metal Local Tissue Reaction Is Associated With Corrosion of the Head Taper Junction. The Journal of Arthroplasty 2012;27-8, Supplement:26-31.e1.

10. Lindgren JU, Brismar BH, Wikstrom AC. Adverse reaction to metal release from a modular metal-on-polyethylene hip prosthesis. Journal of Bone \& Joint Surgery, British Volume 2011:93-B-10:1427-30.

11. Mao X, Tay GH, Godbolt DB, Crawford RW. Pseudotumor in a Well-Fixed Metal-on-Polyethylene Uncemented Hip Arthroplasty. The Journal of Arthroplasty 2012;27-3:493.e13-e17.
} 
12. Bryant M, Ward M, Farrar R, Freeman R, Brummitt K, Nolan J, Neville A. Failure analysis of cemented metal-on-metal total hip replacements from a single centre cohort. Wear 2013;301-1-2:226-33.

13. Donell ST, Darrah C, Nolan JF, Wimhurst J, Toms A, Barker TH, Case CP, Tucker JK, Norwich Metal-onMetal Study G. Early failure of the Ultima metal-on-metal total hip replacement in the presence of normal plain radiographs. J Bone Joint Surg Br 2010;92-11:1501-8.

14. Hothi HS, Berber R, Panagiotopoulos AC, Whittaker RK, Rhead C, Skinner JA, Hart AJ. Clinical signifcance of corrosion of cemented femoral stems in metal-on-metal hips: a retrieval study. International Orthopaedics 2016:1-8.

15. Glyn-Jones S, Roques A, Taylor A, Kwon YM, McLardy-Smith P, Gill HS, Walter W, Tuke M, Murray D. The in vivo linear and volumetric wear of hip resurfacing implants revised for pseudotumor. J Bone Join Surg Am 2011;93-23:2180-8.

16. Kwon YM, Glyn-Jones S, Simpson DJ, Kamali A, McLardy-Smith P, Gill HS, Murray DW. Analysis of wear of retrieved metal-on-metal hip resurfacing implants revised due to pseudotumours. J Bone Joint Surg Br 2010;92-3:356-61.

17. Underwood RJ, Zografos A, Sayles RS, Hart A, Cann P. Edge loading in metal-on-metal hips: low clearance is a new risk factor. Proceedings of the Institution of Mechanical Engineers, Part H: Journal of Engineering in Medicine 2012:0954411911431397.

18. Matthies A, Skinner J, Osmani H, Henckel J, Hart A. Pseudotumors Are Common in Well-positioned Lowwearing Metal-on-Metal Hips. Clinical Orthopaedics and Related Research ${ }^{\circledR}$ 2012;470-7:1895-906.

19. Nawabi D, Nassif N, Do H, Stoner K, Elpers M, Su E, Wright T, Potter H, Padgett D. What Causes Unexplained Pain in Patients With Metal-on metal Hip Devices? A Retrieval, Histologic, and Imaging Analysis. Clinical Orthopaedics and Related Research ${ }^{\circledR}$ 2014;472-2:543-54.

20. Lord JK, Langton DJ, Nargol AVF, Joyce TJ. Volumetric wear assessment of failed metal-on-metal hip resurfacing prostheses. Wear 2011:272-1:79-87.

21. Matthies AK, Racasan R, Bills P, Blunt L, Cro S, Panagiotidou A, Blunn G, Skinner J, Hart AJ. Material los at the taper junction of retrieved large head metal-on-metal total hip replacements. J Orthop Res 2013;31 11:1677-85.

22. Morlock MM, Bishop N, Zustin J, Hahn M, Rüther W, Amling M. Modes of Implant Failure After Hip Resurfacing: Morphological and Wear Analysis of 267 Retrieval Specimens. Vol. 90, 2008:89-95.

23. Hothi HS, Whittaker RK, Meswania JM, Blunn GW, Skinner JA, Hart AJ. Influence of stem type on material loss at the metal-on-metal pinnacle taper junction. Proceedings of the Institution of Mechanical Engineers, Part H: Journal of Engineering in Medicine 2015;229-1:91-7.

24. Sidaginamale RP, Joyce TJ, Bowsher JG, Lord JK, Avery PJ, Natu S, Nargol AV, Langton DJ. The clinical implications of metal debris release from the taper junctions and bearing surfaces of metal-on-metal hip arthroplasty: joint fluid and blood metal ion concentrations. Bone Joint J 2016;98-b-7:925-33.

25. Hothi HS, Matthies AK, Berber R, Whittaker RK, Skinner JA, Hart AJ. The Reliability of a Scoring System for Corrosion and Fretting, and Its Relationship to Material Loss of Tapered, Modular Junctions of Retrieved Hip Implants. The Journal of Arthroplasty 2014;29-6:1313-7.

26. Brock TM, Sidaginamale R, Rushton S, Nargol AVF, Bowsher JG, Savisaar C, Joyce TJ, Deehan DJ, Lord JK, Langton DJ. Shorter, rough trunnion surfaces are associated with higher taper wear rates than longer, smooth trunnion surfaces in a contemporary large head metal-on-metal total hip arthroplasty system. Journal of Orthopaedic Research 2015;33-12:1868-74.
27. Hothi HS, Eskelinen AP, Berber R, Lainiala OS, Moilanen TPS, Skinner JA, Hart AJ. Factors Associated With Trunnionosis in the Metal-on-Metal Pinnacle Hip. The Journal of Arthroplasty.

28. Cook RB, Shearwood-Porter NR, Latham JM, Wood RJK. Volumetric assessment of material loss from retrieved cemented metal hip replacement stems. Tribology International 2015;89:105-8.

29. Hart AJ, Ilo K, Underwood R, Cann P, Henckel J, Lewis A, Cobb J, Skinner J. The relationship between the angle of version and rate of wear of retrieved metal-on-metal resurfacings: A PROSPECTIVE, CT-BASED STUDY. Journal of Bone \& Joint Surgery, British Volume 2011;93-B-3:315-20

30. Witt F, Bosker BH, Bishop NE, Ettema HB, Verheyen CCPM, Morlock MM. The Relation Between Titanium Taper Corrosion and Cobalt-Chromium Bearing Wear in Large-Head Metal-on-Metal Total Hip Prostheses. Vol. 96, 2014:e157.

31. Tuke M, Taylor A, Roques A, Maul C. 3D linear and volumetric wear measurement on artificial hip joints Validation of a new methodology. Precision Engineering 2010;34-4:777-83.

32. Cook RB, Maul C, Strickland AM. Validation of an Optical CMM for the Measurement of Wear at the Taper Interface in Total Hip Replacement. ASTM STP1591 Modularity and Tapers in Total Joint Replacement Devices 2015.

33. Bisseling P, Tan T, Lu Z, Campbell PA, van Susante JLC. The absence of a metal-on-metal bearing does not preclude the formation of a destructive pseudotumor in the hip - a case report. Acta Orthopaedica 2013;844:437-41.

34. Windler M. Korrosionsverhalten von modularen Verbindungen bei Hüftprothesen. Departement Werkstoffe. ETH Zurich, 2003

35. Kamali A. Hip Joint Tribology. In: McMinn DW, ed. Modern Hip Resurfacing: Springer London, 2009:79-89

36. Hu XQ, Wood RJK, Taylor A, Tuke MA. The tribological behaviour of different clearance MOM hip joint with lubricants of physiological viscosities. Proceedings of the Institution of Mechanical Engineers, Part $\mathrm{H}$ Journal of Engineering in Medicine 2011;225-11:1061-9.

37. McMinn DJW. Modern Hip Resurfacing. Springer London, 2009.

38. Willert HG, Broback LG, Buchhorn GH, Jensen PH, Koster G, Lang I, Ochsner P, Schenk R. Crevice corrosion of cemented titanium alloy stems in total hip replacements. Clin Orthop Relat Res 1996-333:51-75.

39. Howell JR, Blunt LA, Doyle C, Hooper RM, Lee AJC, Ling RSM. In Vivo surface wear mechanisms of femoral components of cemented total hip arthroplasties: the influence of wear mechanism on clinical outcome. The Journal of arthroplasty 2004;19-1:88-101.

40. Bolland BJ, Culliford DJ, Langton DJ, Millington JP, Arden NK, Latham JM. High failure rates with a largediameter hybrid metal-on-metal total hip replacement: clinical, radiological and retrieval analysis. J Bone Joint Surg Br 2011;93-5:608-15

41. Thomas SR, Shukla D, Latham PD. Corrosion of cemented titanium femoral stems. J Bone Joint Surg Br 2004;86-7:974-8.

42. Burston BJ, Wood JH, Lewis JR, Prosser GH, Firth L, Wood DJ, Yates PJ. High Failure Rates of the Spectron EF Stem at a Minimum of 10\&\#x2005;Year’s Follow-up. The Journal of Arthroplasty;29-10:1956-60. 